\title{
APPLICATION OF INFORMATION COMMUNICATION TECHNOLOGIES IN THE STUDY PROCESSES OF THE UNIVERSITIES OF THE THIRD AGE
}

\author{
Irena Žemaitaityte \\ Mykolas Romeris University, Lithuania \\ Agne Balčiūnaite \\ Mykolas Romeris University, Lithuania
}

\begin{abstract}
The article reviews the experience of people arranging studies involving information and communication technologies into the University of the Third Age studies organization. Life expectancy is longer and the birth rate is lower in proportion to older age people; due to these facts, the ageing is even more noticeable. This situation requires certain measures, which would be effective in the future. Non-formal education institutions, including University of the Third Age, react to the changes and offer trainings which help older people to maintain workingcapacity, physical, social and psychological health. In order to provide greater benefits, it is important to pay attention not only to the students of the Third Age but to the needs and changes of society on the whole. It is obvious that in the twenty-first century life is hardly imaginable without information-communication technologies (ICT), which are not only rapidly growing and modifying but are also integrating and changing each and every one aspects of people`s lives, regardless of their age. Therefore, it is extremely important that elder persons have at least minimal of computer literacy and ICT skills in order to conform to modern society standards.
\end{abstract}

Keywords: information communication technologies, older adults, non-formal adult education, University of the Third Age.

\section{Introduction}

Fast ageing of the society, growing emigration, plunge in birth rate in Lithuania motivate the society to acknowledge the ever-expanding segment of society, the elderly adults. At the start of 2011 in Lithuania there lived 484,7 thousand or 13,9 percent of elderly people. The forecast is that in the year 2030 Lithuania will see almost a third of its population (28,9 percent ) as aged people (EU 27-30,4 percent), the part of society aged 80 and older will increase 1,5 times (Zumeras, 2013). Because of these reasons, new challenges and new requirements arise for the present society. Adult learning and education is one of the possibilities to deal with such societal problems as increase in adult people`s work 
engagement, and adaptation mechanisms to the changing conditions. Universities of the Third Age help this vulnerable group of society become a fully established group, to develop as individuals and to share interests with others, to become more fit physically, psychologically and socially. The extended life span of people, the growing number of elderly people provide grounds for opening Universities of the Third Age where people could learn new and develop already acquired content, perfect their qualifications, choose from a variety of courses, and satisfy the need of learning and socialisation. The older adults often indicate the need for self-realisation; wish to develop and to communicate with others as the motives for learning. At present in Lithuania (Statistic, 2016) there function 70 non-formal adult education schools, which structure their function not only along specific needs of adult learning and education but also along the fast changing society and the developmental direction towards "the knowledge society". One of the key reflective aspects of the modern society is the application of the information communication technologies (ICT). Though a spectrum of technologies have found its way to Lithuania relatively recently (they were first introduced to Lithuania 20-30 years ago), many older adults have no skills, no intention nor possibilities to use ICT, which are critical for successful function in the society.

The paper seeks to discuss the experience of people who organise studies with the application of information and communication technologies to the study processes at the Universities of the Third Age.

\section{The role and input of information communication technologies to the function of the Universities of the Third Age}

We cannot image today`s life without computers, mobile phones, the Internet nor without technologies functioning in the broadest sense of their understanding. They are introduced in many diverse companies (where manual labour is substituted by the computerised work, digitalised content, introducing of different software or even robotics), public life (electronic systems are operating in public transport, in electronic banking, in car rentals), politics (many politicians open their personal web pages; a system for online voting is under construction), and other areas of life, education being one of them (studies are arranged through distance, computers, tablets, other technological devices are used as tools for preparation and display of presentations; and the like). The spread of technologies is happening regardless of the age group, which is going to be exposed to their complexity and use; therefore, all age groups will have to adapt to be able to function appropriately in modern society. New technologies are cable and satellite television, computerised communication, personal computers, new bureau technologies, specifically online information services (Webster, 2006; Tomczyk, 2010). Tomczyk, (2010) define information technologies as a totality of 
information processing methods and tools. Researchers identify that the effect of new technologies on the humanity is multiple: it is related to building material and spiritual values, and social-cultural environment (Wagner \& Kozma, 2005; Dagienè, 2008; Feist \& McDougall, 2013). The accent falls on the characteristics that the skills to use ICT are indispensable for all social groups and layers. They are instrumental for the successful participation in societal life. Modern ICT are applied to many areas of societal life, therefore, abilities and skills to use them are of importance to all groups of society.

Petkunas (2007) while dealing with the effects of the Information Communication Technologies upon the educational paradigm, separates two approaches - educational and technological. Technological approach sees ICT as a supporting means to diversify traditional pedagogy; while educational approach connects ICT to the changes that happen to the learning and teaching. Most often technologies are developed to easily a human life. In education technologies also easily the access of individual needs to studies, also they are developed for the modernisation of the whole educational process. Tolutiene and Puskorius (2014) highlight the fact that the main goal of ICT use in education is to modernise the process of education and to provide conditions to seek modern goals of education: 1) to develop important societal skills for complete life in the knowledge society (abilities to learn, critical thinking, creativity, information technology skills); 2) to update teaching content and to integrate diverse data; 3) to apply new teaching methods; 4) to form new learning and life culture. These goals are oriented to the learning individual and the individual adaptation to the fast changing society.

The Universities of the Third Age (UTA) are institutions of non-formal adult education, which provide non-formal teaching for older people and continuous studies, to harmonise their knowledge and competences with the developmental needs and cultural requirements (Zemaitaityte, 2014). The main goals of the nonformal education of the University of the Third Age are:

- $\quad$ to help an individual to satisfy self-learning needs, to develop cultural interests;

- $\quad$ to develop personal creative skills and capacities;

- to help an individual to become an active citizen of the democratic society;

- $\quad$ to provide conditions for acquiring theoretical training and practical skills for professional activities and for augment of the qualification competences (Analysis of UTA system performance, 2012).

The University of the Third Age participates in finding solution to one of the fundamental goals of adult education in society; the UTA provides an opportunity for older adults to adapt to the evolving situation and to implement personal needs. Researchers (D'Orazio \& Florenzano, 2000; De Camillis, 2000; Zemaitaityte, 
2007; Gustaitiene \& Beneviciene, 2014) state that the UTA guarantee a better integration of older adults into society, enrich their life; sustain their labour condition; keep up standards of information, culture; let them share their life experiences. This form of education is acceptable for older adults, it helps critically to self-reflect and assess their life conditions, to find new potentials for upgrading living conditions and to start constructive alterations. In Lithuania the UTA is often seen as a cooperation of elderly people for the achievement of different goals of action (not only academic growth, but also artistic function, tourism, and the like) and self -development (Analysis of UTA system performance, 2012). This explains how the study process serves the needs of the society and the students. The persons who arrange the study processes are oriented towards these spheres and pay a lot of attention to the needs of UTA students. The Universities of the Third Age appeared in Lithuania in a relatively recent period (in 1995 the first UTA was founded and until 20088 more universities opened on the initiative of private individuals). After 2008 the situation changed and the universities were opened on the initiative of the local municipalities and other universities. In spring 2014 in Lithuania there functioned Universities of the Third Age in 40 towns; they encouraged education of older adults, upgraded life quality of elderly people, contributed to the cultural, social, and physical well-being of the older adults. In arranging the educational processes technologies often are taken as aids, yet, technologies play an important part in the study process, they let arrange the studies in a more effective way and for larger audiences of people, achieve positive microclimate, diversify study process, give students new opportunities for learning to use ICT and, what is of paramount importance, apply them on day-to-day basis.

\section{Methodology of Research}

In the attempt to identify the experiences of the people who arrange studies with modern ICT into the curriculum of the UTA, a qualitative survey was carried out. It is chosen because of the holistic approach to the object, extraction of qualitative data, openness of the research, the acknowledgement of the instrumental status of the researcher for obtaining knowledge, acquiring and putting to practice experience in describing the object of the survey itself. Bitinas states (2006) that holistic approach to the object is when the object is seen as a single complex system. The researcher seeks to reveal categories and dimensions, to penetrate the details, to interpret all within the context of the totality. The attention is paid to the processes of education, the evolution of the individuals and cultures (Kvale, 2007; Yin, 2011; Flick, 2014). This approach makes the researcher identify the ICT application opportunities and also measure the value of the application of the ICT as a detail in educational process for the whole 
process and, most importantly, for the informants, personally. For the purpose of the research the narrative strategy is chosen, when the data selection method is a semi-structured interview method. 11 interviews were carried out with the average length of an individual interview - $40 \mathrm{~min}$. The data was recorded, transcribed, printed and a qualitative data analysis for the narratives was carried out.

The University of the Third Age was chosen on the principle of availability, targeted selection was undertaken. In selecting the university the data of 20122013 research „Analysis of the University of the Third Age System Function“ was studied regarding the major Universities of the Third Age functioning in Lithuania at the moment of research. The invitation was sent to the representatives of all faculties who organise studies with the expectation to receive diversified answers without any prior attitude. Research participants - people who arrange study processes at the University of the Third Age. Research ethics issues - the informants were provided with the letters of agreement to participate in the survey which were signed by signatures or other credentials. All informants were participating on a voluntary basis. The survey material in the transcribed matter and in the analysis does not reveal a single informant's personal data. All the names, surnames and other data for the identification of the persons were changed at the researcher`s advice. The data was processed ethically. The citations provided in the work were not changed after the agreement of the informants was granted. The data was coded by the authentically listed phrases.

\section{Analysis of the Research Data}

In the analysis of the informants` responses, three main themes were identified: study processes organisation; application of the Information Communication Technologies; process valuation. This article seeks to focus on one of the themes - application of the Information Communication Technologies to the organisation of the study processes of the University of the Third Age.

In the period of research it became obvious that the informants mostly spoke of the type of Information Communication Technologies which they use in their work, in other words, the participants of the research did not touch in their discussions upon the technologies they are not using directly in organising study processes, neither they talked about broader opportunities that ICT maybe applied to. While reviewing the experiences of the informants to use ICT the focus was directed towards their importance to the experiences of the informants and their opinions of ICT tools. The organisers defined ICT in very general terms, stressing the fact, that Information Communication Technologies at the moment are very important in life, and in the University of the Third Age: "ah, those information technologies, well but work without hem is not impossible" ("ai, tos informacines, nu bet darbas dabar neimanomas be ju. "), "Let`s say a teacher, an 
Žemaitaityte \& Balčiūnaite, 2018. Application of Information Communication Technologies in the Study Processes of the Universities of the Third Age

andragogue, or any other teacher in these days cannot be imagined without Information Communication Technologies“ (,Ir sakysim, ir dèstytojui, andragogui, ar kitam dèstytojui, sakysim, jau šiais laikais be tokiu komunikaciniu informaciniu technologiju, sunku isivaizduoti. "), "But in the present time they are the engine of life “(„Bet šiais laikais jos yra gyvenimo variklis. “), "you know, there might have been a time when all seemed very frightening, since we are older people, at the end of our employment careers we had to work on computers, a lot, and now we cannot imagine without a computer" ("žinot, kažkada, gal atrode, tokia kaip, nu kažkoks baisus dalykas, mes vis tiek jau esam vyresnio amžiaus, tai tiesiog tai buvo, kad bebaigiant darbinę karjera jau teko dirbti kompiuteriu ir daug teko dirbti, o dabar tai neisivaizduojama be kompiuterio "), "It is clear, that in these days we could not live without it. No Dean is without a computer and without all those connections that are inevitable and necessary." (, ,Tai aišku neịmanoma nebütu šiais laikais gyvent. Ir nei vienas dekanas jau nèra be kompiuterio be tu visu ryšiu kurie neišvengiami ir bütini. "), "this imagination is, I gather, very limited, but on the other hand present day life without them is unimaginable, without these technologies" (tas isivaizdavimas mūsu taip pat, labai sakyčiau toksai ribotas yra, bet iš kitos pusès, be ju, šiuolaikinis gyvenimas neimanomas yra, be situ technologiju“"). It is possible to notice, that the informants stress the importance of ICT in the organising of the study process, delivering lectures, life and call them "the vehicle of life". Also the informants identified the impossibility to work without computers at the present moment of time. This means that computers are classified as one of the key means of ICT but in the past they were "frightening to use". Many Deans of the University of the Third Age are elderly people and ICT for them is quite a novelty. Study organisers when listing devices that they associate with ICT named the following tools: a computer, the Internet, an email, a mobile phone, a camera, a tablet, multimedia "it associates with computers, of course, the Internet, all. First, of course, computers, then smart phones, then a variety of different programmes which we as our forefathers used to say never dreamed of came and other things." („asocijuojasi su kompiuteriais, be abejo, internetas, viskas. Pirmiausia, aišku kompiuteriai, paskui išmanieji telefonai, paskui ịvairiausios ịvairiausios programos, kuriu mes anksčiau, kaip sakydavo mūsu senoliai, ir sapnuot nesapnavom, ir kiti dalykai."), "I hear that the tablets are now very popular and people of my age, many use tablets, for cameras, they have all.“ (,,Planšetès dabar girdžiu yra labai populiarios, ir mano amžiaus žmonès daug kas planšetes naudoja. ir fotoaparatas, ten viskas yra"), "so its a computer. An email. Mobile devices. Local phones.“ („, tai kompiuteriu. Elektroniniu paštu. Mobiliomis ryšio priemonemis. Vietiniu telefonu."), "we ourselves, personally, have no such possibilities to use some fancy devices beside the Internet, beside a computer. Let `s say if this is a lecture so in it other devices are used as well multimedia, so 
far, but so far so.“ (,,mes patys, asmeniškai, neturim tokiu galimybiu panaudoti kažkokius ypatingus prietaisus, apart interneto, apart kompiuterio. Na sakysim, jeigu paskaitoj tai ten panaudojama, reiškia, ir kitas, ir multimedija, kol kas, bet jau taip jau. "). Some less used devices were also highlighted: television and radio, the portal of the University of the Third Age, recordings, phonograms - "it is possible to say that we use recordings for phonograms“ (,galima sakyti, kad irašus naudojam, pavyzdžiui būna fonogramos"), "Very broadly used is our University page. Where you can find the newest information, or, let`s say the principle that everyone can be noticed and everyone can have one`s say and you can immediately find on the internet page." ("Ir labai plačiai yra naudojamas mūsu svetaines puslapis. Kur, sakysim, pati naujausia informacija yra pateikiama arba šitas, sakysim, kokia, vat pavyzdžiui, pas mus yra laikomasi, kad kiekvienas turi būt pastebètas, kiekvienas turi būt išklausytas, ka tu iš karto sužinai, ka tu pastebi ir pateiki iš karto internetiniam puslapy."), "I speak on televison, very often speak over the radio“ (,kalbu ir per televizija, labai dažnai kalbu per radija "). These answers show a broader understanding of our informants of what are Information Communication Technologies, but most often it comes down to the devices and technologies that they personally use.

While analysing the interviews the informants`experience in learning to use Information Communication Technologies came forth. The Organisers told their stories of how they learned to use ICT devices, who taught them, who motivates them to develop their skills. A part of the informants learned independently, a part attended courses, trainings. Some of the survey participants defined the learning process in both ways: "In technologies I am self-taught. I am not skilled myself, yet. I wanted to attend courses.“ (,, ogi technologijomis tai aš savamokslè. Ir dabar gi aš gerai nemoku. Norèjau eiti $j$ kursus "), "At first I could not attach a letter, then I learned with that clip, then there are many other things. And I started using them because I had to translate a book from Polish.“ (,pradžioj gi nemokejjau prisegti laiško, tai išmokau su ta squaržéle, paskui gi yra visokiu kitokiu ka tau reikia, kažkokiu. Ar dar, o pradejau naudotis tai ko gero tuo, kad reikejo versti knyga iš lenku kalbos); "In this way by sitting and picking with one finger trying to push every arrow mark and in this way I learned myself.“ (,vat taip sedint, vienu pirštu badant, ir ieškant kur čia kokia rodykle pastumti, va taip per kažkoki tai laika, pats per save ir išmokau"), "Perhaps as the majority of people, reading instructions, my children helped, I attended computer courses.“ („,Matyt kaip ir didžioji dauguma žmoniu, ir instrukcijos skaitymas, ir padèjo mano vaikai, padejo, lankiau ten kompiuteriu kursus "), "I learned independently, sometimes I need help, so I ask, of course, of my children and of my colleagues, in the other work.“ (,pati savarankiškai, kai kur kai kada reikia pagalbos, tai aš be abejonès kreipiuosi, ir $i$ vaikus ir šalia, kolegas, ir ten kitame darbe"). The survey results reveal that the learning process associates for the survey participants with 
Žemaitaityte \& Balčiūnaite, 2018. Application of Information Communication Technologies in the Study Processes of the Universities of the Third Age

different methods: self-studies, learning from colleagues, learning with others, attending courses, or a special school. This provides the spectrum of learning opportunities and adult learners find suitable methods of learning new things when the life situation changes, sometimes overcoming difficulties. This is confirmed by the „self-taught“ informants` answers: “ first, the son put up a simple computer for me, showed Word, so I figured out Word and started typing with one figure, learned to save, so that it would not disappear, archive so this was my first work. Later the Internet came, I was very interested in Internet.“ (,pirmu pirmiausia tai sūnus pastatè toki man prasta kompiuteri, na worda parodè, tai worda supratau ir pradèjau rašinèti su tuo vienu pirštu, supratau kaip užsiseivint kaip sakant, užseivint kad jis nepradingtu man, šiek tiek dokumentuot ir va toks pirmasis darbas buvo. O toliau jau buvo internetinis darbas, toliau labai domejausi“). However, in the courses and trainings the informants experienced certain emotions - "I was taught by a certain Vytautas, doctor of sciences, and I could not, practically, understand him, he was very friendly, caring, laborious, but for me it was too sophisticated.“ („toks Vytautas dèstè mums, mokslu daktaras ir aš jo, nu galima sakyti nesupratau, labai jisai buvo ir draugiškas ir darbštus ir rūpestingas ir iš tikruju rimtai dèstè, bet man tai buvo per aukštas lygis"), "But as I came there for the first time, I saw all types of computers, I am shy I sat at the back of the room at a box , similar to a dog`s kernel. I tried to switch it on, but even the teacher had trouble in switching it on. She started explaining of how I can put pictures, texts and I saw that for me these things are unintelligible and I did not go there anymore“ (,Bet atejau aš pirma syki, tenai pridèta visokiu tipu tu kompiuteriu, nesu nachalas, atsisèdau ten toli, tokia děžè, dar tokia kaip šunio būda. Aš bandžiau ijungti, bet vos ir ta dèstytoja ir ta mokytoja vos ijungè. Ir kaip pradèjo jinai aiškinti, kaip dèlioti i tekstus paveikslèlius, aš pamačiau, kad čia man neịkertami dalykai ir aš ten daugiau nejjau"). The experience of the informants indicates certain specificity of work with the elderly people: the information has to be presented clearly; it has to be repeated as many times as the elderly students need to understand the provided topic. However, some organisers when studying ICT were younger, middle aged, yet this learning was new to them, something difficult to understand. "So, how to use the menu I seem to know, its logic, and here is a different logic, and different thinking has to be. Then when you take this as we called mobile phone and it was not for me alone, a sweat breaks out.“ (,Na kaip tuo meniu naudotis, atrodo, pripratęs vat tokia logika, o čia kita logika, kitas mąstymas turi büt. Pirma atsisèdi, ne man vienam čia, prie to telefono, kaip mes vadindavom, mobiliojo, atsisédi ir prakaituoji“.)

This experience the informants associate with their employment, personal needs. "I did not know anything 20-30 years ago, I did not know anything about computers and , finally, when I was 80 , my wife a bit younger, we bought a computer and started learning and working with it.“ („Aš nieko, prieš 20-30 metu, 
nieko nežinojau apie kompiuterius, ir pagaliau turèdamas 80 metu, žmona jaunesnè šiek tiek, mes nusipirkome kompiuterị ir pradejome kažkiek tai mokytis dirbti su juo"), " at that time computerisation just started and I changed my job to a place where, practically, without computer skills was impossible to make a move.“ (,tais laikais, tik prasidejjo kompiuterizacija ir aš perejjau dirbti toki darba, kur praktiškai be kompiuterio buvo nei žingsnio.”) It is possible to state that the informants were put into the position to learn ICT skills by their employment when computers were started to be used in Lithuania. Though only a few came across technologies immediately but a part of informants acknowledged that they were motivated to study IT devices since the day of their appearance because of their work position. Informants said that they had to study independently and to obtain technological devices was too costly. "They said the price that I paid for my cooperative flat, so that is what they said. <..> Then my brother bought a car, there was a car „žiguliai“ and the computer was more expensive than that car." (,,ir pasake tada tokia kaina, aš buvau užmokéjusi pinigus už kooperatini buta, va tiek pasake. <...> O tada brolis, pirko automobili, tai žiguliai buvo toks automobilis, tai buvo brangiau už ta automobili kompiuteris“). At that moment computers did not perform any communicative function and no information could be trasnmitted, but they accumulated, archived and carried out other functions. Later when the internet was introduced, computers were renewed their functions updated, they became ICT devices and new things were to be learned. This learning process in the opinion of the informants has to continue since these devices come out with updated functions, and the life of the informants and their activities require studying of new skills.

Speaking of ICT learning experiences the survey participants mentioned who taught them to use ICT. It turned out that most often the informants learned from the „young“, members of the family, colleagues and self-dependently. „I have a son, rather young, so it is clear that apart from the young people`s or without the colleagues` help we learn from each other.“ („Aš turiu sūnu toki dar sąlyginai jauna, tai aišku be jaunimo pagalbos arba be kolegu pagalbos, vieni iš kitu mokomés"), "My family has a person whose function is to help with Information Technologies. If I need something or something fails, or a problem arises, something not clear, I call and ask "Come“ and that is.,, („mano šeimoje yra žmogus, kur jo tiesioginis darbas informacinès technologijos. Jeigu jau tik man ko nors reikia, sugedo kas nors, neaišku kas nors, ar kaip, aš paskambinu „atvažiuok" ir viskas"), "When sometimes my son helps me, he suggests to give me theory, but I respond, that I do not need theory, I will not put myself into it, just say which button to press, „mum, you forgot“", "I will take it down, now.“ (,Bet na aš tai, na sūnus kai kada padeda, sako aš tau pasakysiu teorija, sakau vaikeli man nereikia teorijos, aš neužsiimsiu, tegul, pasakyk kokius mygtukus man čia suspaudyt. „, tu mama užmirši “, na aš užsirašysiu. "), "I wanted to upgrade a 
bit, so here is a UTA faculty of information technologies. I asked the Dean to be introduced into the group.“ („Aš dar norèjau šiek tiek patobulèti čia TAU fakultetas yra informacinès technologijos, ... paprašiau dekano, kad jis leistu mane $i$ grupe“.) The answers the informants provided prove that UTA study processes organisers seek to upgrade their skills continually. They emphasised that they seek for learning aid in the immediate environment, among family members, friends and at work or other engagements. It is possible to state that young family members while training their elders participate vicariously in the organising the University of the Third Age study processes through application of the ICT.

While talking about learning to use ICT the informants mentioned the Faculty of Information Technologies, which provides teaching in computer literacy. It was noted that some Deans wish to enlist in the programme, some have already studied there since they wanted to be more literate in this area. Thus, the Faculty is important not only for the prospective students but for the organisers of the study processes themselves. "Perhaps we should mention that now there is that faculty, a new one, Information Technologies, so there is the place for those who have no computer literacy, to acquire it first of all.“ (,Reiketu gal prisiminti, dabar yra tas fakultetas, naujas informaciniu technologiju, tai ten aišku, kaip ir reikia, kad mokytusi pirmiausia, tie, kurie iš viso neturi kompiuterinio raštingumo, kad išmoktu“), "we prepare our seniors of the Third Age not only for the immediate life, but also for them to be able to use those communication technologies for enhancing their life quality.“ (,,mes savo Trečiojo amžiaus senjorus, ruošiam tokiam ne tik tai betarpiškam gyvenimui, bet kad jie ir tas komunikacines technologijas panaudotu ir savo gyvenimo kokybess pagerinimui “). The informants pointed to the students' needs while talking of ICT, they emphasised that it is important for students to study to use ICT for better life quality. However, to quote informants, some are illiterate in computer information, though their numbers are shrinking; most start learning because life conditions make them study.

\section{Conclusions}

In summing up, it is possible to state that the application of ICT in the University of the Third Age is rather wide. In the broadest sense, ICT could be applied as a teaching tool, learning environment, communication, administration and the task performance tool. The results of the survey showed that ICT application in organising studies at the University of the Third Age depends on the individuals who organise the studies, however, the process is influenced by the material resources of the institution, the specificity of the faculty, as well as the needs of the students and other individuals and the possibilities to use ICT. 
The participants of the survey stated that almost all processes of study organising include ICT use. The research revealed that the Deans experienced relative difficulties in learning to use ICT devices, but these skills unquestionably make the organising of the processes easier as well as enhance their personal lives. At the present moment the informers learn from the "young "members of their families, colleagues and other persons. These people through their assistance in using ICT take vicarious participation in the organising of study processes at the University of the Third Age.

\section{References}

Analysis of UTA system performance (2012). Retrieved from http://www.upc.smm.lt/ svietimas/tyrimai/TAU\%20tyrimo\%20ataskaita\%202012.pdf

Dagienè, V. (2008). Informacinès mokymo technologijos. Vilnius: VU.

De Camillis, S. (2000). Motivazioni all'educazione continua. Perché gli adulti frequentano i corsi di studio per tutto l'arco della vita. Roma: EdUP.

D'Orazio, E., \& Florenzano, F. (2000). Studiare da grande. Conoscere e fare le università della terza età. Roma: EdUP.

Feistm, H., \& McDougall, K. (2013). Older people's use of new communication technologies: Research Findings \& Policy Implications. Australian Population \& Migration Research Centre Policy Brief, Vol. 1, No. 8.

Gustaitienè, L., \& Benevičienė, V. (2014). Vyresnio amžiaus žmonių psichologinių bei socialinių veiksnių, psichosocialinio prisitaikymo ypatumai socialinių ir demografinių duomenu atžvilgiu. Socialinis darbas, 13, 248-262.

Petkūnas, V. (2007). The Cange of Educational Paradigm under the Influence of ICT Implementation: Reseach on Students' Attitudes. Socialiniai mokslai, 3 (57), 54-65.

Statistics 2015. (2016). Vilnius: Statistics Lithuania.

Tolutienè, G., \& Puskorius, S. (2014). Informacinių ir komunikacinių technologijų taikymas švietime: besimokančių suaugusiujų. Požiūrio tyrimas. Tiltai, 3, 123-140.

Tomczyk, L.(2010). Seniorzy w świecie nowych mediów. E-mentor, 4 (36).

Wagner, D. A., \& Kozma, R. (2005). New Technologies for Literacy and Adult Education: A Global Perspective. UNESCO.

Webster, F. (2006). Informacines visuomenès teorijos. Vilnius: UAB „Poligrafija ir informatika“.

Zumeras, R. (2013). Pagyvenusių žmoniu fizinis aktyvumas ir sveikata. Vilnius. Sveikatos mokymo ir ligu prevencijos centras.

Žemaitaitytè, I. (2007). Neformalusis suaugusiuju švietimas: plètros tendencijos dabartinejje Europoje: monografija. Vilnius: Mykolo Romerio universitetas.

Žemaitaityte, I. (2016). Older adult education in Lithuanian ageing society. Society. Health. Welfare. Vol. 30 p. 1-9. DOI: 10.1051/shsconf/20163000023 